\title{
The effect of different oils and diets on methane release in an artificial rumen (Rusitec) ${ }^{*}$
}

\author{
D. Jalčํ, A. Cieślak², M. Szumacher-Strabel², A. Potkański \\ and J. Kowalczyk ${ }^{3}$ \\ ${ }^{1}$ Institute of Animal Physiology, Slovak Academy of Sciences \\ Soltesovej 4-6, 04001 Košice, Slovak Republic \\ ${ }^{2}$ The August Cieszkowski Agricultural University of Poznań, \\ Department of Animal Nutrition and Feed Management \\ Wotyńska 33, 60-637 Poznań, Poland \\ ${ }^{3}$ The Kielanowski Institute of Animal Physiology and Nutrition, Polish Academy of Sciences \\ 05-110 Jabtonna, Poland
}

\begin{abstract}
The effect of three different diets (100\% fresh lucerne, Experiment I; fresh lucerne/ maize 60:40, Experiment II; fresh lucerne/maize 40:60, Experiment III) and fat sources (linseed, rapeseed, fish oil, $5 \% \mathrm{wt} \cdot \mathrm{wt}^{-1}$ ) on methane production was studied in vitro. In experiment IV, $60 \%$ fresh lucerne $+40 \%$ maize was supplemented with $5 \% \mathrm{wt} \cdot \mathrm{wt}^{-1}$ of oil blends. Methane production was significantly reduced $(\mathrm{P}<0.05)$ mainly in the diet with linseed and fish oils (24 and 23\%, respectively; Experiment I). The control diet consisting of fresh lucerne was characterized by the highest methane production $\left(9.77 \mathrm{mMd}^{-1}\right)$ when compared with the control diets rich in concentrate $\left(4.75 \mathrm{mMd}^{-1}\right)$.
\end{abstract}

KEY WORDS: artificial rumen, lucerne, maize, oils, oil blends, methane

\section{INTRODUCTION}

Methane emission from domestic ruminants is responsible for up to $25 \%$ of total anthropogenic methane production (Khalil, 2000) and is considered to be the second most important greenhouse gas (Wuebbles and Hayhoe, 2002). This phenomenon not only affects the environment but also has financial implications for farmers. By reducing methane emission it is possible to save up to $12 \%$ of

\footnotetext{
* Supported by the Grant Agency of the Slovak Academy of Sciences, Grant No. 2/6174/6 and the State Committee for Scientific Research (Poland), Grant No. 3 P06Z 05923

${ }^{1}$ Corresponding author: e-mail: jalcd@saske.sk
} 
the gross energy (GE) intake of ruminants (Johnson et al., 1993; Moss et al., 1994). Scientists are therefore looking for ways to reduce methane production from rumen. Fat-enriched diets may reduce methane emission (Moos et al., 2000). Giger-Reverdin et al. (2003) showed, however, that unsaturated fatty acids originating from oil may disturb the rumen ecosystem, and this fact should be taken under consideration. The objective of the present study was to compare rations comprising three different proportions of fresh lucerne and maize supplemented with different oils and their blends on methane production in an in vitro simulation system (Rusitec).

\section{MATERIAL AND METHODS}

The rumen simulation technique and rumen supply for Rusitec equipment was described by Jalč et al. (2006a). On days 8-13, gas samples were collected and the methane concentration $\left(\mathrm{mM}\right.$ day $\left.^{-1}\right)$ was determined by gas chromatography (Perkin-Elmer 8500). Mean values from each treatment were compared with one-way analysis of variance (ANOVA). Treatment means were compared by the Tukey-Kramer multiple comparison test.

\section{RESULTS AND DISCUSSION}

In the present study the control forage diet was characterized by the highest methane production $\left(9.77 \mathrm{mM} \mathrm{d}^{-1}\right)$ when compared with the control high concentrate diet ( $4.75 \mathrm{mM} \mathrm{d}^{-1}$; Table 1). Similar results were obtained by Cieślak et al. $(2005 \mathrm{a}, \mathrm{b})$ after analysing diets composed of hay and concentrate in different proportions. Previous experiments showed that fats containing mainly unsaturated fatty acids (UFA) are inhibitors of methane emission, but with varied efficiency (Cieślak et al., 2005b). The forage diet (Experiment I) supplemented with LO and FO significantly reduced methane production (24 and 23\%, respectively). Methane production was not reduced by supplemented rapeseed oil (Table 1). Fermentation of the hay diet supplemented with canola oil and cod liver oil $(10 \%$ $\mathrm{wt} \cdot \mathrm{wt}^{-1}$ ) was characterized by suppression of methane production by 26 and $29 \%$, respectively (Dong et al., 1997). Our results also point to a certain toxic effect of polyunsaturated fatty acids (PUFA) in oils on bacteria that are involved in methanogenesis. Inhibitory effects of PUFA on methanogens can be expected (Nagaraja et al., 1997). In experiment II, linseed and fish oil supplementation to the mixed forage-concentrate diet $(60: 40 \%)$ did not significantly reduce methane production although the differences were 22 and 5\%, respectively for LO and FO in comparison with control. Rapeseed oil supplementation slightly increased methane 
Table 1. Methane production from different diets supplemented with linseed (LO), rapeseed (RO), fish oil (FO) or with oil blends, $\mathrm{mlday}^{-1}$

\begin{tabular}{|c|c|c|c|c|c|}
\hline \multirow{2}{*}{ Items } & \multirow{2}{*}{ Control } & \multicolumn{3}{|c|}{ Added oil, $5 \% \mathrm{wt} \mathrm{wt}^{-1}$} & \multirow{2}{*}{ Pooled \pm SEM } \\
\hline & & LO & $\mathrm{RO}$ & FO & \\
\hline \multicolumn{6}{|c|}{ Experiment } \\
\hline \multirow[t]{2}{*}{ I } & \multicolumn{5}{|c|}{$100 \%$ fresh lucerne } \\
\hline & $9.77^{\mathrm{a}}$ & $7.43^{\mathrm{b}}$ & $9.83^{\mathrm{a}}$ & $7.53^{\mathrm{b}}$ & 0.32 \\
\hline \multirow[t]{2}{*}{ II } & \multicolumn{5}{|c|}{$60 \%$ fresh lucerne $+40 \%$ maize } \\
\hline & $7.11^{\mathrm{ab}}$ & $5.53^{\mathrm{b}}$ & $7.52^{\mathrm{a}}$ & $6.75^{\mathrm{ab}}$ & 0.26 \\
\hline \multirow[t]{2}{*}{ III } & \multicolumn{5}{|c|}{$40 \%$ fresh lucerne and $60 \%$ maize } \\
\hline & $4.75^{\mathrm{ab}}$ & $4.16^{\mathrm{b}}$ & $6.01^{\mathrm{a}}$ & $4.77^{\mathrm{ab}}$ & 0.27 \\
\hline \multirow[t]{3}{*}{ IV } & \multicolumn{5}{|c|}{$40 \%$ fresh lucerne and $60 \%$ maize } \\
\hline & Control & $\mathrm{LO} / \mathrm{RO}$ & $\mathrm{FO} / \mathrm{LO}$ & $\mathrm{FO} / \mathrm{LO} / \mathrm{RO}$ & \\
\hline & $8.69^{\mathrm{a}}$ & $6.13^{\mathrm{b}}$ & $7.23^{\mathrm{ab}}$ & $9.07^{\mathrm{ab}}$ & 0.32 \\
\hline
\end{tabular}

C - control; LO - linseed oil; RO - rapeseed oil; FO - fish oil; LO/RO - linseed/rapeseed oil; $\mathrm{FO} / \mathrm{LO}$ - fish/linseed oil; FO/LO/RO - fish/linseed/rapeseed oil; means with the same letter are not significantly different at $\mathrm{P}<0.05$

production (about 6\%), but these differences were not significant (Table 1). A similar tendency was observed when rapeseed oil was added to diets comprising hay and concentrate (60:40), but the differences were significant when methane emission was related to fermented organic matter (Cieślak et al., 2005a). Dohme et al. (2001) reported that the supply of certain fatty acids to ruminant diet seems to have the potential to reduce methan release depending on a different source of UFA, like oil plant seeds. The reduction in methane production induced by rapeseed and linseed supplementation $\left(3-6 \% \mathrm{wt}^{\cdot} \mathrm{wt}^{-1}\right)$ was 13.6 and $31.2 \%$ when these oilseeds were added to the diet containing maize silage, hay and concentrate in a Rusitec (Machmüller et al., 1998). In experiment III, oil supplementation to a mixed concentrate-forage diet $(60: 40 \%)$ had a different, but not significant, effect on methane production. Methane release was not significantly reduced by linseed oil (12\%) and was elevated by rapeseed and fish oils ( 26 and $0.5 \%$, respectively). The opposite results were found when diets rich in concentrate supplemented with 5\% in DM of rapeseed, linseed and sunflower oil. Methane production was significantly $(\mathrm{P}<0.01)$ suppressed $(16 \%)$ in vitro and numerically (15\%) in vivo (Cieślak et al., 2005b). In Experiment 4, methane release per day was significantly $(\mathrm{P}<0.05)$ reduced $(29.5 \%)$ with $(\mathrm{LO}+\mathrm{RO})$ blends, numerically reduced with (LO+FO) blends, and slightly (4\%) increased (NS) with $(\mathrm{FO}+\mathrm{LO}+\mathrm{RO})$ blends. Consequently, a combination of plant oils (LO+RO) showed a greater suppressive effect on methane production than did a combination of plant and fish oils (LO+FO; Table 1). 


\section{CONCLUSIONS}

Methane release was reduced mainly with $\mathrm{LO}$ or FO and oil blends (LO+RO). Moreover, $\mathrm{CH}_{4}$ production reached a higher level in the full forage diet, a lower level in mixed forage-concentrate diets, and the lowest values in the mixed concentrate-forage diet.

\section{REFERENCES}

Cieślak A., Soliva C.R., Potkański A., Szumacher-Strabel M., Scheeder M.R.L., Machmüller A., 2005a. Effect of plant oils on methane emission and biohydrogenation in vitro. GGAA, Zurich, pp. 456-459

Cieślak A., Soliva C.R., Potkański A., Szumacher-Strabel M., Machmüller A., 2005b. Effects of rapeseed, sunflower or linseed oil supplementation on methane production in vitro and in vivo. GGAA, Zurich, pp. 460-463

Dohme F., Machmüller A., Wasserfallen A., Kreuzer M., 2001. Ruminal methanogenesis as influenced by individual fatty acids supplemented to complete ruminal diets. Lett. Appl. Microbiol. 32, $47-$ 51

Dong Y., Bae H.D., Mc Allister T.A., Mathison G.W., Cheng K.J., 1997. Lipid induced depression of methane production and digestibility in the artificial rumen system (Rusitec). Can. J. Anim. Sci. 77, 269-278

Giger-Reverdin S., Morand-Fehr P., Tran G., 2003. Literature survey of the influence of dietary fat composition on methane production in dairy cattle. Livest. Prod. Sci. 82, 73- 79

Jalč D., Potkański A., Szumacher-Strabel M., Kowalczyk J., Cieślak A., 2006a. Effect of forage diet and different fat sources on rumen fermentation in vitro. J. Anim. Feed Sci. 15, Suppl. 1, 129-134

Johnson D.E., Hill T.M., Ward G.M., Johnson K.A., Branine M.E., Carmean B.R., Lodman D.W., 1993. Ruminants and other animals. In M.A.K. Khalil (Editor). Atmospheric Methane: Sources, Sink, and Role in Global Change. Springer-Verlag, Berlin, Heidelberg, pp. 199-229

Khalil M.A.K., 2000. Atmospheric methane: an introduction. In: Atmospheric Methane: Its Role in the Global Environment. Springer-Verlag, Berlin, pp. 1-8

Machmüller A., Ossowski D.A., Wanner A., Kreuzer M., 1998. Potential of various fatty feeds to reduce methane release from rumen fermentation in vitro (Rusitec). Anim. Feed Sci. Tech. 71, $117-130$

Moss A.R., Deaville E.R., Givens D.I., 1994. Effect of supplementing grass silage with sugar beet feed on methane production by sheep. Proc. Brit. Soc. Anim. Prod., Paper No. 53

Moss A.R., Jouany J.P., Newbold C.J., 2000. Methane production by ruminants: its contribution to global warming. Ann. Zootech. 49, 231-253

Nagaraja T.G., Newbold C.J., Van Nevel C.J., Demeyer D.I., 1997. Manipulation of ruminal fermentation. In: P.N. Hobson, C.S. Stewart (Editors). The Rumen Microbial Ecosystem. 2nd Edition. Blackie Academic and Professional, London, pp. 523-632

Wuebbles D.J., Hayhoe K., 2002. Atmospheric methane and global change. Earth-Sci. Rev. 57, $117-210$ 